\title{
Pengaruh Model Pembelajaran Berbasis Masalah Berbantuan Media Phet Terhadap Hasil Belajar Fisika Siswa Kelas X SMAN 1 Gunungsari Tahun Pelajaran 2015/2016
}

\author{
Tantawi Jauhari ${ }^{1}$, Hikmawati ${ }^{2}$, Wahyudi ${ }^{2}$ \\ 1) Alumni Program Studi Pendidikan Fisika \\ 2) Dosen Program Studi Pendidikan Fisika \\ Universitas Mataram \\ Mataram, Indonesia \\ Email: jauhary.thanthawi93@gmail.com
}

\begin{abstract}
This research aims to find out the effect of problem based learning model with PhET media on the student's results of physics learning of $X^{\text {th }}$ grade SMAN 1 Gunungsari in academic year 2015/2016. This research is a quasi experiment with nonequivalent control group design. The population of this research is all of $X^{\text {th }}$ grade student which amounted to 333 students, and the sample is the student at X.6 which amounted to 34 student as experiment class and student at X.7 which amounted to 35 student as control class. The sample was got by using the cluster purposive sample. The result of pre-test showed that the average value of experiment class is 34,35, while the control class around 43,66. The result of post-test showed that the average value of experiment class is 70,24, while the control class around 57,60. The study tested the hypothesis with $t$-test polled varians. Based on the result of hypothesis testing, $t_{\text {count }}=4,93$ and $t_{\text {table }}=1,99$ with significance level of $5 \%$ and $t_{\text {count }}>t_{\text {table, }}$, then $H_{o}$ rejected and $H_{a}$ accepted. So can be concluded that there is an effect of problem based learning model with PhET media on the student's results of physics learning of $X^{\text {th }}$ grade SMAN 1 Gunungsari in academic year 2015/2016.
\end{abstract}

Keywords: problem based learning, PhET media, results of physics learning

\section{PENDAHULUAN}

Pendidikan merupakan suatu proses perubahan sikap dan perilaku seseorang dalam upaya mendewasakan manusia melalui proses pembelajaran. Pendidikan juga mempunyai peranan penting dalam kemajuan suatu negara, karena maju tidaknya suatu negara pada masa yang akan datang dapat dilihat dari mutu pendidikan yang ada di negara tersebut. Oleh karena itu, pengembangan IPTEK (Ilmu Pengetahuan dan Teknologi) dan kebutuhan masyarakat yang semakin meningkat, perlu diimbangi dengan peningkatan mutu pendidikan. Salah satu upaya yang telah dilakukan pemerintah adalah penyempurnaan kurikulum 1994 menjadi kurikulum 2006 yaitu Kurikulum Tingkat Satuan Pendidikan (KTSP).

Dalam KTSP untuk pendidikan dasar dan menengah disebutkan bahwa sains berfungsi untuk mengembangkan keterampilan wawasan dan kesadaran teknologi dalam kaitan dengan pemanfaatannya bagi kehidupan sehari-hari. Hal ini berarti, melalui pembelajaran sains di sekolah, semestinya dapat digunakan untuk membentuk kemampuan manusia yang utuh, dalam arti mempunyai sikap, kemampuan kognitif, dan keterampilan memecahkan permasalahan yang dihadapi. Ketiga aspek tersebut tercermin di dalam Undang-Undang No. 20 Tahun 2003 tentang Sistem Pendidikan Nasional, pasal 3 menyebutkan, bahwa pendidikan nasional bertujuan untuk mengembangkan potensi peserta didik agar menjadi manusia yang beriman dan bertakwa kepada Tuhan Yang Maha Esa, berakhlak mulia, sehat, berilmu, cakap, kreatif, mandiri, dan menjadi warga negara yang demokratis serta bertanggung jawab.

Ilmu Pengetahuan Alam (IPA) berkaitan dengan cara mencari tahu tentang fenomena alam secara sistematis, sehingga IPA bukan hanya penguasaan kumpulan pengetahuan yang berupa fakta-fakta, konsep-konsep, atau prinsip-prinsip saja tetapi juga merupakan suatu proses penemuan. Fisika sebagai salah satu cabang dari IPA merupakan ilmu yang lahir dan berkembang lewat langkah-langkah observasi, perumusan masalah, penyusunan hipotesis, pengujian hipotesis melalui eksperimen, penarikan kesimpulan, serta penemuan teori dan konsep. Hal ini sesuai dengan hakikat IPA yaitu adanya proses ilmiah, produk ilmiah, dan sikap ilmiah, maka dalam pembelajarannya fisika menekankan pemberian pengalaman langsung 
kepada siswa dalam mempelajari fenomena alam melalui kegiatan ilmiah [1].

Berdasarkan hasil observasi selama melaksanakan Praktek Pengalaman Lapangan (PPL) di SMAN 1 Gunungsari, didapatkan bahwa pembelajaran fisika yang diterapkan di kelas masih berorientasi pada guru dan kurang memperhatikan aktivitas siswa selama proses pembelajaran.Metode mengajar yang diterapkan dominan ceramah sehingga pembelajaran berpusat pada guru (teacher center). Aktivitas seperti ini dinilai kurang optimal karena hanya membentuk interaksi searah saja, yaitu interaksi guru terhadap siswa, sedangkan melalui wawancara dengan salah satu guru, peneliti mendapatkan informasi bahwa siswa kurang termotivasi belajar fisika. Siswa cenderung hanya mendengar dan mencatat informasi-informasi yang diberikan. Dampak dari permasalahan-permasalahan tersebut adalah pada hasil belajar fisika siswa rendah yang masih berada di bawah KKM, yaitu 75 .

Berdasarkan uraian di atas,peneliti akan mencoba memberikan suatu alternatif model pembelajaranyang dapat memberikan keleluasaan pada siswa untuk membangun pengetahuannnya dan menemukan atau menerapkan sendiri ide-ide mereka sehingga terlibat secara aktif dalam proses pembelajaran.Salah satu pengajaran yang menyediakan kesempatan belajar sendiri bagi siswa adalah model pembelajaran berbasis masalah. Pembelajaran berbasis masalah merupakan model pembelajaran yang dirancang agar peserta didik mendapat pengetahuan penting, membuat mereka mahir dalam memecahkan masalah, dan memiliki strategi belajar sendiri serta memiliki kecakapan berpartisipasi dalam tim. Proses pembelajarannya menggunakan pendekatan yang sistemik untuk memecahkan masalah atau menghadapi tantangan yang nanti diperlukan dalam karier dan kehidupan sehari-hari [2]. Menurut model pembelajaran berbasis masalah, permasalahan yang disajikan adalah suatu permasalahan nyata yang bisa dilihat dalam kehidupan sehari-hari sehinggamenyuguhkan fisika dalam fenomena/masalah yang lebih konkrit.

Untuk lebih mengoptimalkan model pembelajaran berbasis masalah di dalam kelas, maka peneliti mencoba menggunakan bantuan media pembelajaran. Salah satu media yang dapat digunakan adalah PhET yaitu media simulasi interaktif yang mengajak siswa untuk belajar simulasi interaktif berbasis penemuan dan digunakan untuk memperjelas konsep-konsep fisis [3]. Berdasarkan uraian di atas, maka peneliti tertarik untuk melakukan penelitian berjudul "Pengaruh Model Pembelajaran Berbasis Masalah berbantuan Media PhET terhadap Hasil Belajar Fisika Siswa Kelas X SMAN 1 GunungsariTahun Pelajaran 2015/2016".

\section{TINJAUAN PUSTAKA}

\section{A. Model Pembelajaran Berbasis Masalah}

Model Pembelajaran Berbasis Masalah (PBM) atau dalam Bahasa Inggris disebut juga Problem Based Instruction (PBI)merupakan salah satu model pembelajaran inovatif yang menjadikan siswa sebagai pusat dalam pembelajaran yang memberikan kondisi belajar aktif kepada siswa. Model pembelajaran ini juga mengacu pada model pembelajaran yang lain, seperti pembelajaran berdasarkan proyek (Project-based instruction), pembelajaran berdasarkan pengalaman (experiencebased instruction), belajar otentik (authentic learning), dan pembelajaran bermakna (anchored instruction) [4].

Model Pembelajaran Berbasis Masalah merupakan suatu pendekatan dalam pembelajaran dimana siswa menggunakan masalah yang ada di dunia nyata untuk belajar berpikir kritis dan memperoleh kemampuan memecahkan masalah serta memperoleh pengetahuan dan konsep yang esensi dari materi pelajaran [5]. Pada awal kegiatan belajar siswa diperkenalkan atau diberikan suatu masalah yang sering dijumpai dalam kehidupan sehari-hari. Karena masalah yang semakin dekat dengan dunia nyata, akan semakin baik pengaruhnya pada peningkatan kecakapan siswa [2]. Pembelajaran Berbasis Masalah ini benar-benar memberikan kesempatan bagi siswa untuk membangun sendiri konsep yang dipelajari berdasarkan pemecahan masalah. Dalam memecahkan masalah siswa bekerjasama dalam kelompoknya sehingga terjadi pertukaran pikiran yang dapat membangun penyelesaian masalah. Berdasarkan uraian para ahli di atas, peneliti dapat simpulkan bahwa model Pembelajaran Berbasis Masalah adalah suatu pola pembelajaran yang menekankan pada pemecahan suatu masalah nyata yang dihadapi oleh siswa secara berkelompok untuk 
memperoleh suatu konsep yang hendak dipelajari secara ilmiah.

\section{B. Media PhET}

Media berasal dari kata medius (bahasa Latin) yang berarti perantara atau pengantar, sedangkan dalam bahasa Arab, media adalah perantara atau pengantar pesan dari pengirim kepada penerima pesan. Jadi media adalah alat yang menyampaikan atau mengantarkan pesan-pesan pembelajaran [6]. Lebih lanjut media pembelajaran didefinisikan sebagai segala sesuatu yang dapat menyampaikan dan menyalurkan pesan dari sumber secara terencana sehingga tercipta lingkungan belajar yang kondusif, di mana penerimanya dapat melakukan proses belajar secara efisien dan efektif [7].

PhET (Physics Education Technology) adalah salah satu media simulasi yang dibuat oleh University of Colorado yang berisi simulasi pembelajaran fisika, biologi, dan kimia untuk kepentingan pengajaran di kelas atau belajar individu. Simulasi PhET menekankan hubungan antara fenomena kehidupan nyata dengan ilmu yang mendasari, mendukung pendekatan interaktif dan konstruktivis, memberikan umpan balik, dan menyediakan tempat kerja kreatif [8].

Berdasarkan uraian beberapa pendapat ahli di atas, dapat disimpulkan bahwa media PhET adalah suatu perantara atau alat berupa program simulasi interaktif berbasis virtual yang dapat digunakan untuk menyampaikan pesan-pesan atau informasi dalam pembelajaran fisika.

\section{Hasil Belajar}

Hasil belajar dapat dijelaskan dengan memahami dua kata yang membentuknya, yaitu "hasil" dan "belajar". Pengertian hasil mengarah pada suatu perolehan akibat dilakukannya suatu aktivitas atau proses yang mengakibatkan berubahnya input secara fungsional. Belajar dilakukan untuk mengusahakan adanya perubahan perilaku pada individu yang belajar. Perubahan perilaku merupakan perolehan yang menjadi hasil belajar. Hasil belajar perlu dievaluasi. Evaluasi dimaksudkan sebagai cermin untuk melihat kembali apakah tujuan yang ditetapkan telah tercapai dan apakah proses belajar mengajar telah berlangsung efektif untuk memperoleh hasil belajar [9]. Lebih lanjut hasil belajar di definisikan sebagai pola-pola perbuatan, sikap-sikap, apresiasi dan keterampilan [10].
Berdasarkan uraian di atas, maka dapat disimpulkan bahwa hasil belajar fisika siswa adalah kemampuan maksimal seseorang yang dicapai setelah melalui proses pembelajaran fisika dengan model pembelajaran berbasis masalah berbantuan media PhET yang dapat diukur dan dinyatakan dalam bentuk angka melalui kegiatan evaluasi.

\section{METODE PENELITIAN}

Jenis penelitian ini yaitu penelitian quasi experiment.Penelitian quasi experiment merupakan pengembangan dari true experiment (eksperimen sungguh-sungguh). Dalam penelitian quasi experiment tidak sepenuhnya peneliti mampu mengontrol variabel-variabel luar yang mempengaruhi hasil eksperimen[11]. Penelitian ini dilaksanakan sejak agustus 2014 hingga juni 2016 yang bertempat di SMAN 1 Gunungsari kabupaten Lombok Barat.Desain penelitian menggunakan Nonequivalent Control Group Design. Populasi dalam penelitian ini yaitu seluruh siswa kelas $\mathrm{X}$ SMAN 1 Gunungsari yang terbagi dalam 9 kelas. Teknik pengambilan sampel menggunakan cluster purposivesampling sehingga diperoleh kelas X6 sebagai kelas eksperimen dan kelas X7 sebagai kelas kontrol. Kelas eksperimen diberi perlakuan model pembelajaran berbasis masalah berbantuan media $\mathrm{PhET}$, sedangkan kelas kontrol diberi pembelajaran konvensional.

Pengumpulan data dalam penelitian ini dilakukan dengan metode tes menggunakan tes pilihan ganda sebanyak 25 soal yang telah dipilih sesuai kriteria analisis uji instrumen, meliputi analisis validitas, reliabilitas, taraf kesukaran, dan daya beda soal. Tes dilakukan sebanyak dua kali yakni tes awal (pre-test) dan tes akhir (posttest).Pre-test dilakukan sebelum kegiatan pembelajaran untuk mengetahui kemampuan awal siswa terhadap materi pelajaran.Oleh karena itu, pada data hasil pre-test dilakukan uji homogenitas menggunakan Uji Varians (Uji F).Sementara itu, post-test dimaksudkan untuk mengetahui hasil belajar siswa terhadap materi pelajaran setelah kegiatan pembelajaran.Analisis data hasil post-test meliputi uji normalitas (Chi Kuadrat), homogenitas (Uji Varians), dan hipotesis.Uji normalitas digunakan untuk mengetahui normalitas data guna menentukan uji statistik dalam uji hipotesis.Uji homogenitas untuk uji lanjut statistik parametrik 
yang digunakan jika data terdistribusi normal.Uji hipotesis dilakukan untuk mengetahui pengaruh model pembelajaran berbasis masalah berbantuan media PhET terhadap hasil belajar fisika siswa.

\section{HASIL DAN PEMBAHASAN}

Hasil penelitian berupa deskripsi data pre-test dan post-test. Hasil pre-test kelas eksperimen dan kontroldapat dilihat dalam tabel 1 berikut.

Tabel 1 Hasil Pre-Test Kelas Eksperimen dan Kontrol

\begin{tabular}{|c|c|c|}
\hline \multirow{3}{*}{ Komponen } & \multicolumn{2}{|c|}{ Hasil Pre-Test } \\
\hline & Kelas & Kelas \\
\hline & Eksperimen & Kontrol \\
\hline Jumlah siswa & 34 & 35 \\
\hline Nilai tertinggi & 68 & 60 \\
\hline Nilai Terendah & 16 & 16 \\
\hline Rata-rata & 34,35 & 43,66 \\
\hline Standar Deviasi & 11,61 & 10,73 \\
\hline Hasil Uji & \multirow{2}{*}{\multicolumn{2}{|c|}{ Homogen }} \\
\hline Homogenitas & & \\
\hline
\end{tabular}

Berdasarkan data pada tabel 1 , terlihat nilai rata-rata kelas eksperimen $(34,35)$ lebih rendah dibandingkan kelas kontrol $(43,66)$. Nilai rata-rata kedua kelas di atas masih berkategori rendah karena di bawah KKM.Berdasarkan hasil uji homogenitas kedua kelas adalah homogen. Hal ini berarti kedua kelas memiliki kemampuam awal yang sama sebelum diberikan perlakuan. Selanjutnya hasil post-test kelas eksperimen dan kontroldapat dilihat dalam tabel 2 berikut.

Tabel 2 Hasil Post-Test Kelas Eksperimen dan Kontrol

\begin{tabular}{|c|c|c|}
\hline \multirow{3}{*}{ Komponen } & \multicolumn{2}{|c|}{ Hasil Post-Test } \\
\hline & Kelas & Kelas \\
\hline & Eksperimen & Kontrol \\
\hline Jumlah siswa & 34 & 35 \\
\hline Nilai tertinggi & 92 & 84 \\
\hline Nilai Terendah & 40 & 32 \\
\hline Rata-rata & 70,24 & 57,60 \\
\hline Standar Deviasi & 11,91 & 9,26 \\
\hline $\begin{array}{l}\text { Hasil Uji } \\
\text { Normalitas }\end{array}$ & Normal & Normal \\
\hline $\begin{array}{l}\text { Hasil Uji } \\
\text { Homogenitas }\end{array}$ & \multicolumn{2}{|c|}{ Homogen } \\
\hline $\begin{array}{l}\text { Uji } t \text {-test polled } \\
\text { varians }\end{array}$ & \multicolumn{2}{|c|}{$\begin{array}{l}t_{\text {hitung }}>t_{\text {tabel }}, \mathrm{H}_{\mathrm{o}} \text { ditolak dan } \\
\mathrm{H}_{\mathrm{a}} \text { diterima }\end{array}$} \\
\hline
\end{tabular}

Hasil post-test pada tabel 2 di atas, memperlihatkan bahwa nilai rata-rata kelas eksperimen $(70,24)$ lebih tinggi dari kelas kontrol $(57,60)$. Hasil ini menunjukkan bahwa kedua kelas sama-sama mengalami peningkatan.Namun, peningkatan nilai rata-rata yang dialami kelas eksperimen lebih dari dua kali peningkatan nilai rata-rata kelas kontrol.Hasil post-test kemudian uji normalitas menggunakan rumus chi-kuadrat, diperoleh bahwa data kedua kelas adalah normal.Hal ini berarti uji hipotesis menggunakan statistik parametrik.Hasil perhitungan uji homogenitas diperoleh bahwa kedua kelas adalah homogen, berarti statistik parametrik yang digunakan yaitu, $t$ test polled varians pada taraf signifikan $5 \%$. Uji hipotesis menggunakan t-test polled varians diperoleh $t_{\text {hitung }}=4,93$, lebih besar dari $t_{\text {tabel }}=1,99$. Hal ini berarti terdapat pengaruh model pembelajaran berbasis masalah berbantuan media PhET terhadap hasil belajar fisika siswa kelas $\mathrm{X}$ SMAN 1 Gunungsari tahun pelajaran 2015/2016.

Uraian di atas menunjukkan bahwa kelas eksperimen yang diberikan perlakuan model pembelajaran berbasis masalah berbantuan media PhET memiliki kemampuan akhir kognitif yang lebih tinggi dilihat dari peningkatan hasil belajarnya daripada kelas kontrol yang diberikan perlakuan model pembelelajaran konvensional. Hal ini disebabkan karenakelas eksperimen yang diberi perlakuan model pembelajaran berbasis masalah berbantuan media PhET lebih aktif dan antusias dilihat dari aktivitas siswa saat mengikuti proses pembelajaran dibandingkan kelas kontrol yang diberi pembelajaran konvensional. Pada awal pembelajaran siswa kelas eksperimen diberipermasalahan dalam Lembar Kegiatan Siswa (LKS) terkait materi kalor yang akan dipelajari. Masalah yang dikemukakan kepada siswa tersebut berupa masalah dalam kehidupan sehari-hari, sehingga siswa lebih mengerti dan paham terhadap masalah yang sedang dihadapi. Terkait masalah yang harus dipecahkan dalam pembelajaran tersebut, siswa dituntut untuk membuat hipotesis (jawaban sementara) sesuai dengan kemampuan awal yang dimiliki. Siswa kemudian dituntut untuk membuktikan hipotesis melalui kegiatan eksperimen menggunakan media PhET.

Kegiatan eksperimen menggunakan media PhET menuntut siswa untuk terlibat aktifdalam 
proses pembelajaran. Meskipun media ini tidak memberikan pengalaman langsung kepada siswa karena tidak menggunakan alat-alat yang konkrit, namun penggunaan media virtual seperti PhET lebih mampu meningkatkan pemahaman siswa.Selama kegiatan eksperimen berlangsung, siswadapat mengamati kesesuaian antara hipotesis dengan fakta yang terjadi terkait eksperimen yang sedang dilaksanakan.Apabila hipotesis yang dibuat siswa terkait masalah sudah sesuai dengan fakta yang terjadi selama proses eksperimen, maka hal ini dapat memperkuat pemahaman siswa mengenai materi yang sedang dipelajari. Sebaliknya, apabila hipotesis yang dibuat oleh siswa belum sesuai dengan fakta yang terjadi selama proses eksperimen, maka hal ini dapat memberikan pemahaman yang benar kepada siswa. Pemahaman yang diperoleh melalui kegiatan eksperimen ini dapat membangun pengetahuan siswa, karena siswa secara aktif terlibat dalam pembelajaran untuk memecahkan masalah.

Data yang diperoleh siswa melalui kegiatan eksperimen menggunakan media PhET selanjutnya digunakan untuk menjawab pertanyaan-pertanyaan yang telah tersedia dalam Lembar Kegiatan Siswa (LKS). Terkait pertanyaan ini, siswa dituntut untuk berdiskusi dengan teman kelompok masing-masing untuk mencari jawaban berdasarkan data yang diperoleh, sehingga siswa dapat bertukar informasi mengenai jawaban yang paling benar untuk setiap pertanyaan. Kemudian hasil eksperimen dan diskusi disampaikan oleh salah satu kelompok di depan kelas dan ditanggapi oleh kelompok lain. Penyampaian hasil eksperimen ini memberikan kesempatan kepada siswa untuk saling bertukar informasi antar kelompok. Selain itu, kekurangan masing-masing kelompok terkait materi kalor dapat diketahui, Sehingga guru dapat memberikan kesimpulan akhir yang benar dan sama pada setiap kelompok.Oleh karena itu, siswa mendapatkan pengetahuan terkait masalah yang disajikan di awal pembelajaran, sehingga siswa dapat menjawab permasalah tersebut.

Berdasarkan uraian di atas, dapat disimpulkan bahwa model pembelajaran berbasis masalah berbantuan media PhET dapat mengaktifkan siswa melalui kegiatan pemecahan masalah. Hal ini dapat dilihat dari aktivitas dan antusias siswa dalam menjalani proses pembelajaran, sehingga berdampak terhadap hasil belajar fisika kelas eksperimen lebih baik dibandingkan kelas kontrol. Pengalaman dalam memecahkan masalah memberikan kesempatan kepada siswa untuk bertukar pikiran dengan anggota kelompoknya, mengembangkan kemampuan berpikir berdasarkan masalah, dan membangun pengetahuannya sendiri.Hal ini sesuai dengan teori yang menyatakan bahwa pembelajaran berbasis masalah memberikan kesempatan kepada siswa untuk belajar berfikir kritis dan memperoleh kemampuan memecahkan masalah yang dihadapai [5].

\section{PENUTUP}

Berdasarkan rumusan masalah, hasil penelitian dan pembahasan, maka dapat disimpulkan bahwa model pembelajaran berbasis masalah berbantuan media PhET berpengaruh terhadap hasil belajar fisika siswa kelas X SMAN 1 Gunungsari tahun pelajaran 2015/2016.

Model pembelajaran berbasis masalah berbantuan media PhET dapat dijadikan sebagai alternatif model pembelajaran yang dapat diterapkan untuk mengaktifkan siswa, sehingga hasil belajar kognisi siswa meningkat.Penerapan model pembelajaran berbasis masalah berbantuan media PhET sebaiknya memperhatikan beberapa hal, yaitu:

a. Alokasi waktu diatur sebaik mungkin sehingga tiap tahapan pembelajaran dapat berlangsung secara maksimal;

b. Menguji kelayakan media PhET yang akan digunakan dalam eksperimen;

c. Memberikan perlakuan khusus bagi siswa yang sulit diatur.

\section{REFERENSI}

[1]Trianto. 2012. Model Pembelajaran Terpadu: Konsep, Strategi, Implementasinya dalam Kurikulum Tingkat Satuan Pendidikan (KTSP). Jakarta: Bumi Aksara.

[2]Amir,Taufik. 2009. Inovasi Pendidikan melalui Problem Based Learning. Jakarta: Kencana Prenada Media Group.

[3]Krisdiana, A., dan Supardi, I. 2015. Penerapan Pembelajaran Guided Discovery pada Materi Fluida Dinamik dengan Media PhET untuk Meningkatkan Hasil Belajar Siswa Kelas XI SMA Negeri 1 Sooko.Jurnal Inovasi Pendidikan Fisika. Vol 04 No 02, 133-140. 
[4]Trianto.2009. Mendesain Model Pembelajaran Inovatif-Progresif:Konsep, Landasan, dan Implementasinya pada Kurikulum Tingkat Satuan Pendidikan. Jakarta: Kencana Prenada Media Group.

[5]Rusman, 2012. Model-Model Pembelajaran. Bandung: Rajawali Pers.

[6]Arsyad, A. 2014. Media Pembelajaran. Jakarta: Rajawali Press.

[7]Munadi, Y. 2010. Media Pembelajaran. Jakarta: Gaung Persada Press.

[8]Finkelstein, Adams, Keller, Perkins, and Wieman. 2006. Hightech Tools For Teaching Physics: The Physics Education Technology Project. MerlotJurnal of Online Learning and Teaching. Vol. 2 (3): 110-121.

[9]Purwanto. 2014. Evaluasi Hasil Belajar. Yogyakarta: Pustaka Pelajar.

[10]Suprijono, A. 2013. Cooperatif Learning. Surabaya: Pustaka Pelajar.

[11]Sugiyono.2014a. Metode Penelitian Pendidikan: Pendekatan Kuantitatif, Kualitatif, dan $R \& D$. Bandung: Alfabeta.

\section{BIOGRAFI PENULIS}

M. Tantawi Jauhari, S.Pd. lahir di Dusun Montong Taker Desa Saba Kecamatan Janapria Kabupaten Lombok Tengah, 17Agustus 1993. Penulis telah menyelesaikan pendidikan di MI NW Kenyalu tahun 2005, MTs NW Embung Raja tahun 2008, dan MA Mua'llimin NW Anjani tahun 2011. Penulis melanjutkan studinya di FKIP Universitas Mataram pada Program Studi Pendidikan Fisika dan lulus tahun 2016. 